\title{
토양측정망 확대 지점의 토양 유기물 함량 연구 Analysis of the Organic Matter Content for Soil Samples Taken at the New Points of Korea Soil Quality Monitoring Network
}

\author{
이소진 · 김진주 · 정승우 ${ }^{\dagger}$ \\ Sojin Lee $\cdot$ Jinjoo Kim $\cdot$ Seung-Woo Jeong ${ }^{\dagger}$ \\ 군산대학교 환경공학과 \\ Department of Environmental Engineering, Kunsan National University
}

(Received September 5, 2016; Revised December 5, 2016; Accepted December 9, 2016)

\begin{abstract}
Soil organic matter (SOM) is an important soil component releasing nutrients to the plants and reducing risks of soil contamination to the human and ecosystem. Much attention has been recently paid to SOM investigation and management because SOM holds the most of carbon in the earth and sequestrate carbon as a sink tank. The first objective of the study was to investigate SOM of 495 soil samples taken at the Korea Soil Quality Monitoring Network. Soil samples were collected from 16 regions and 8 land use types. The second objective of the study was to find a relationship between the Tyurin method and loss-on-ignition (LOI) method for SOM. The means of SOM by Tyurin and LOI methods were 1.90 and $2.92 \%$ (w/w), respectively. Land uses such as forest, religious area and park where organic matters continuously supply to normally showed higher SOMs than residential and school areas having sandy soils. A regression equation of the relationship between Tyurin and LOI methods was $\mathrm{y}($ Tyurin $)=$ $0.6257 x$ (LOI) +0.0602 (P-value $<0.001)$. The coefficient of determination was $\mathrm{R}^{2}=0.749$, relatively linearly related. Although LOI may result in higher SOMs than the Tyurin method, LOI may be a preference for the SOM investigation if various kinds of land uses and many soil samples should be measured.
\end{abstract}

Key Words : Soil Organic Matter, Tyurin Method, Loss-on-ignition, Land Use

요약 : 토양 유기물은 농작물에 영양분을 공급하는 중요한 토양 구성분이며 오염물질의 이동을 감소시켜 인체 및 생태에 미 치는 영향을 완충하는 역활을 한다. 최근 지구온난화를 야기하는 온실기체의 싱크탱크 역활이 부각되면서 토양 유기물에 대 한 조사 및 관리방안에 대한 관심이 고조되고 있다. 본 연구의 목적은 첫째, 환경부 토양측정망 495 개 지점에서 채취한 토양 의 유기물함량을 측정하여 지역별, 토지용도별 토양 유기물함량을 파악하고자 하였고 둘째, 토양 유기물 함량 측정방법인 Tyurin산화법과 강열감량법(LOI)의 상관관계를 조사하였다. Tyurin법과 강열감량법으로 토양 유기물 함량을 조사한 결과 평 균은 각 각 $1.90 \%, 2.92 \%$ 로 나타났다. 토지용도별 유기물 함량 순서는 Tyurin법 및 강열감량법 모두 유사하였다. 여전히 자연 환경 요소가 많이 남아있거나 토양으로 유기물 유입이 지속적으로 일어나는 임야, 종교용지, 공원은 비교적 높은 유기물함량 을 보이나, 유기물 유입이 상대적으로 적은 대지와 대부분 사질토양으로 구성된 학교용지는 낮은 유기물함량을 보였다. Tyurin법과 강열감량법간 회귀분석결과 $\mathrm{y}(\mathrm{Tyurin})=0.6257 x(\mathrm{LOI})+0.0602(\mathrm{P}-\mathrm{value}<0.001)$ 와 같은 회귀식이 얻어졌고 결정계 수 $\mathrm{R}^{2}=0.749$ 로 나타나 상관성이 높았다. Tyurin법과 강열감량법을 비교한 결과 강열감량법의 결과치가 Tyurin법에 비해 크 게 측정되지만 Tyurin법과 상관관계가 성립되는 바 여러 토지용도에서 많은 양의 토양시료를 측정해야 하는 목적에서는 강 열감량법 적용도 가능할 것으로 판단된다.

주제어 : 토양 유기물, Tyurin법, 강열감량법, 토지용도

\section{1. 서 론}

최근 토양 유기물에 대한 연구와 관심들이 늘어가고 있 다. 토양 유기물은 토양의 최적양분관리에 있어 가장 중요 한 요인으로 토양의 생산성을 결정하는 지표이기 때문이다. 토양 속 유기물은 보편적으로 식물 성장에 필요한 질소, 인, 황 같은 여러 영양물질들을 제공해 준다. 토양 유기물 함량 이 $1 \%$ 증가시 토양의 양이온교환능 $(\mathrm{CEC})$ 이 약 $2.3 \mathrm{meq} / 100$ $\mathrm{g}$ 증가되는 것으로 알려져 있으며, ${ }^{1)}$ 유기물은 토양내 공극 을 확보하여 통기성과 수분보유능력도 증진시켜 토양의 물 리성을 또한 개선시킨다. ${ }^{2)}$

토양 유기물은 오염물질의 이동과 확산에도 영향을 미치
며 궁극적으로 토양오염물질이 사람 및 생태계에 미치는 위 해영향을 완충해 주는 역할을 한다. 오염물질이 토양오염 을 야기하여 생태와 인간에게 위해를 미치게 되는데, 토양 유기물은 오염물질이 이동하지 못하도록 직접 흡착하거나 토양 미생물에게 서식지를 제공하여 토양 미생물이 오염물 질을 생분해하므로 위해를 저감시키는 완충기능을 담당한 다. ${ }^{3)}$ 토양오염물질이 인체 및 생태에 미치는 영향을 정량 화하여 평가하기 위한 도구로서 위해성평가가 이용된다. 위 해성평가의 노출평가단계에서는 토양오염물질로부터 수용 체가 노출되는 지하수오염농도, 실내 및 실외공기 휘발성 물질 농도 등 노출농도를 산정하게 되는데 있어 토양 유기 물함량은 필수적인 기본 인자 값이다. ${ }^{4)}$ 
최근 토양 유기물을 보전하여 지구온난화에 미치는 영향 을 최소화해야 한다는 점이 부각되면서 토양 유기물에 대 한 관심이 고조되고 있다. 지구에 존재하는 토양 내 탄소의 양은 2,500 billion ton으로서 대기에 존재하는 800 billion ton, 식물에 존재하는 560 billion ton보다 훨씬 많은 것으로 알려져 있다. ${ }^{5)}$ 토양의 유기탄소가 유실된다면 그 만큼 지 구온난화를 야기할 수 있다. 토양은 탄소를 함유하는 저장 탱크이므로 지구온난화를 직접적으로 또는 간접적으로 완 화시킬 수 있는 중요한 역활을 담당한다. 따라서, 최근 토 양 유기물함량을 평가하여 토양 유기탄소 함량을 보전하거 나 높이고자 하는 다양한 노력들이 활발히 진행되고 있다. 그럼에도 불구하고 토지용도 변경, 도시화, 산업화 및 환경 오염 등으로 토양의 유기물이 고갈되어 가고 있으며 그 속 도는 가속화되고 있다. ${ }^{6}$

토양 내 유기물함량을 측정하는 방법은 습식산화방법 (Tyurin법, Walkely \& Black법) 및 건식연소법(원소자동분 석기법, 강열감량법) 등으로 구분할 수 있다. 우리나라에서 습식산화방법은 Tyurin법, 건식연소법으로는 강열감량법을 널리 사용하고 있다. Tyurin법은 강산성조건에서 중크롬산 칼륨으로 유기탄소를 산화시켜 정량화하는 방법이며 강열 감량법은 $420 \sim 450^{\circ} \mathrm{C}$ 조건에서 유기물을 연소하여 정량화하 는 방법이다. ${ }^{7)}$

농촌진흥청 국립농업과학원에서 운영하고 있는 토양환경 정보시스템 흙토람에는 농경지에 대한 토양 유기물함량정 보를 포함되어 있다. 환경부에서 운영하고 있는 토양측정 망은 전국에 각 16 개 토지용도별로 토양오염기준 항목에 대한 변화를 관측하고 있지만, 유기물함량은 조사하지 않 고 있다. 토양측정망은 2013 년까지 1,500 개 지점으로 운영 되다 2014년부터 500개 지점이 확대되어 현재는 2,000개 지 점에 대해 토양오염기준 항목을 격년제로 관측하고 있다. 본 연구의 목적은 첫째, 최근 확대된 환경부 토양측정망 495 개 지점에서 채취한 토양의 유기물함량을 측정하여 16 개 지역별, 8 개 토지용도별 토양 유기물함량 현황을 파악하고 자 하였고 둘째, 토양 유기물 함량 측정방법인 Tyurin산화 법과 강열감량법의 상관관계를 조사하고자 하였다.

\section{2. 실험방법}

\subsection{Tyurin법}

토양 유기물 함량 분석방법중 하나인 Tyurin법은 중크롬 산을 이용하여 유기물을 산화시켜 유기탄소함량을 측정하 여 유기물함량을 예측하는 방법으로 농촌진흥청(국립농업 과학원)에서 대표적으로 사용하는 방법이다. 균질화된 토 양을 중크롬산칼리 황산혼합용액으로 가열판에서 산화시킨 후 소비된 산화제의 양을 황산제일철암모늄으로 역적정하 여 유기탄소함량 $(\%)$ 으로 나타내었다. 계산한 유기탄소함량 에 공통계수 1.724 를 곱하여 토양 유기물함량 $\%(\mathrm{w} / \mathrm{w})$ 를 구하였다. ${ }^{7)}$

\section{2. 강열감량법(LOI, Loss-on-Ignition)}

강열감량법은 높은 온도로 연소 시 중량이 손실되는데 그 손실되는 양으로 유기물함량을 측정하는 간접적 유기물 측 정 방법이다. ${ }^{8)}$ 국립농업과학원의 토양화학분석법 ${ }^{6)}$ 에는 적 용온도가 $420 \sim 450^{\circ} \mathrm{C}$ 로 되어 있으며 본 연구에서는 $450{ }^{\circ} \mathrm{C}$ 를 적용하였다. 토양오염공정시험기준 ${ }^{9}$ 의 수분함량 분석법 에 따라 $110^{\circ} \mathrm{C}$ 에서 수분을 정량화한 후 $450{ }^{\circ} \mathrm{C}$ 에서 45 분간 가열한 후 감량을 산출하여 유기물함량 $\%(w / w)$ 을 구하였다.

\section{3. 토양 시료채취}

2014년 확대된 토양측정망 495개 지점에서 토양시료를 채취하였다. 495 개 지점은 강원, 경기, 경남, 경북, 광주, 대 구, 대전, 부산, 서울, 세종, 울산, 인천, 전남, 전북, 충남 및 충북 등 우리나라 전역에 고루 분포하고 있다. 토지용도(지 목)별은 공원, 답, 대지, 임야, 전, 종교용지, 체육용지 및 학 교용지 등이다. 각 지역에서 토양오염공정시험기준에 의거 하여 농경지는 지그재그형으로, 기타지역은 중심지점과 사 방위의 토양시료를 채취하였다. ${ }^{10)}$

채취된 토양시료는 $2 \mathrm{~mm}$ 체로 친 후 통과시료에 대해 Tyurin법과 강열강량법에 의한 유기물함량을 측정하였다. 강열감량법이 적용된 지점은 495 개이며 Tyurin법이 적용된 지점은 338 개이다. 그리고 Tyurin법과 강열감량법을 같이 적용하여 유기물 함량을 측정한 지점은 309 개였다.

\section{3. 결과 및 고찰}

\subsection{Tyurin 방법에 의한 토양 유기물함량 측정 결과}

Table 1은 2014년 확대된 환경부 토양측정망 338 개 지점

Table 1. Measurement of the organic matter content (\%) of soil taken from Korean soil quality monitoring network point by using the Tyurin method

\begin{tabular}{|c|c|c|c|c|c|c|c|c|}
\hline \multicolumn{8}{|c|}{ Regions } & \multirow[b]{2}{*}{ Total } \\
\hline & \multicolumn{3}{|c|}{ Gangwon Gyeonggi } & $\begin{array}{l}\text { yyeong- } \mathrm{G} \\
\text { nam }\end{array}$ & $\begin{array}{l}\text { Gyeong- } \\
\text { buk }\end{array}$ & Gwangju & Daegu & \\
\hline Count & 46 & \multicolumn{2}{|c|}{49} & 6 & 68 & 2 & 2 & \\
\hline Average & 2.4 & \multicolumn{2}{|c|}{1.7} & 2.9 & 1.7 & 0.2 & 3.3 & \\
\hline \multirow[t]{2}{*}{ St. dev } & 2.0 & \multicolumn{2}{|c|}{1.4} & 1.6 & 1.2 & 0.2 & \multirow[t]{2}{*}{0.4} & \\
\hline & Seoul & \multicolumn{2}{|c|}{ Incheon } & $\begin{array}{l}\text { Jeon } \\
\text {-nam }\end{array}$ & Jeonbuk & 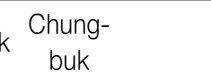 & & \\
\hline Count & 17 & \multicolumn{2}{|c|}{23} & 68 & 44 & \multicolumn{2}{|l|}{13} & 338 \\
\hline Average & 2.2 & \multicolumn{2}{|c|}{1.5} & 1.9 & 1.9 & \multicolumn{2}{|l|}{1.5} & 1.90 \\
\hline \multirow[t]{3}{*}{ St. dev } & 1.6 & & 4 & 1.0 & 1.4 & 1.3 & & 1.42 \\
\hline & \multicolumn{7}{|c|}{ Land uses } & \\
\hline & Park & $\begin{array}{l}\text { Paddy } \\
\text { field }\end{array}$ & $\begin{array}{l}\text { Resi- } \\
\text { dential }\end{array}$ & Forest & Field & Religious & School & Total \\
\hline Count & 14 & 57 & 6 & 186 & 19 & 21 & 35 & 338 \\
\hline Average & 1.8 & 1.9 & 1.8 & 2.0 & 1.6 & 1.9 & 1.6 & 1.90 \\
\hline St. dev & 1.4 & 1.0 & 1.7 & 1.4 & 1.3 & 1.1 & 2.1 & 1.42 \\
\hline
\end{tabular}



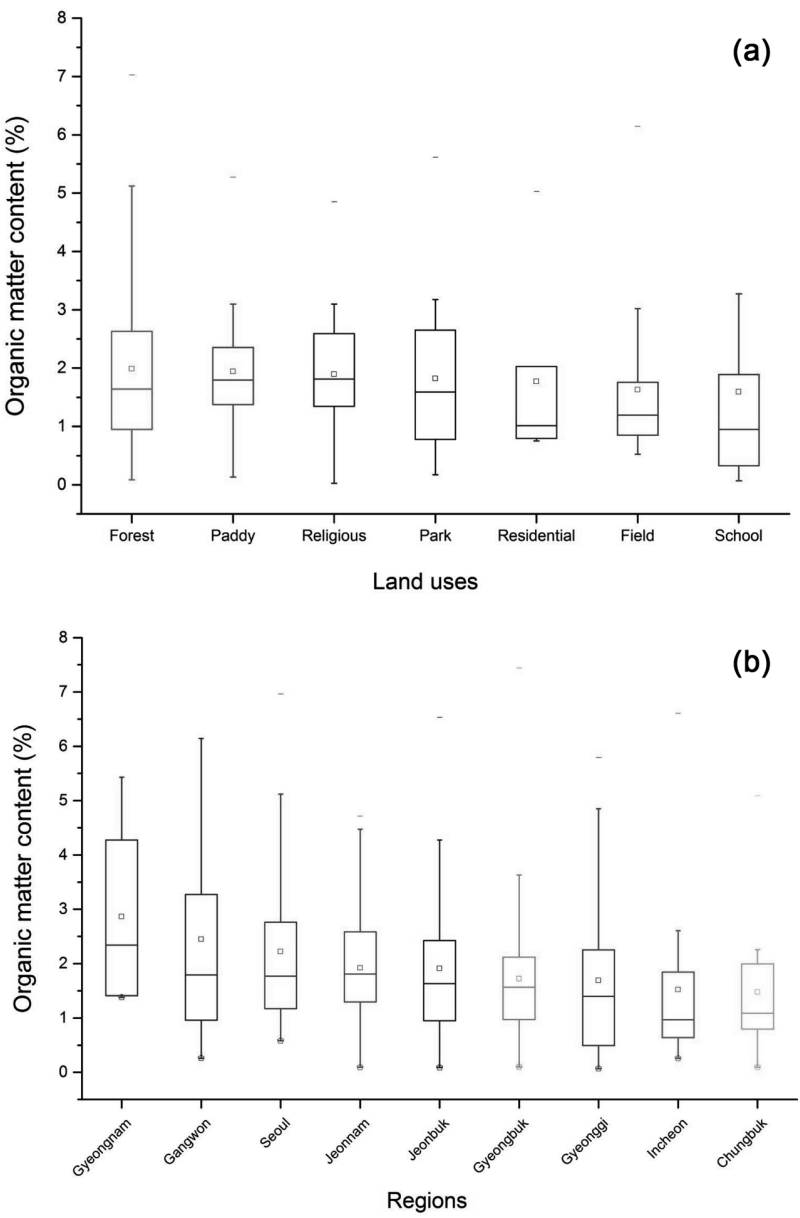

Fig. 1. Soil organic matter contents measured by Tyurin method for land uses and regions.

을 선정하여 Tyurin방법으로 토양 유기물 함량을 조사한 결과이다. 측정결과는 지역별과 토지용도별로 정리하였다. 338 개 지점의 Tyurin법에 의한 토양 유기물 함량은 평균 $1.90 \%$ 로 나타났다. Fig. 1은 box plot으로 평균(mean), 중간 값 (median) 및 사분위도 (quartile) 등 측정결과의 세부 분포 를 도시하고 있다. 지역별 결과 중 광주 및 대구의 측정값이 2개 밖에 되지 않아 box plot에서 제외하였다.

Fig. 1(a)은 Tyurin방법에 의한 토지용도별 토양 유기물함 량 측정결과 평균값이 높은 순서부터 Box plot을 나열하여 정리하였다. 토양 유기물 함량 평균값의 순서는 임야, 논, 종교용지, 공원, 대지, 밭, 학교용지 순이었다. 임야의 평균 유기물 함량은 $2.0 \%$ 였으며 가장 낮은 학교용지는 $1.6 \%$ 였 다. 자연환경 요소가 많이 남아있거나 유기물 유입이 지속 적으로 일어나는 임야, 종교용지, 공원은 비교적 높은 유기 물함량을 보이나, 반면 유기물 유입이 상대적으로 적을 것 으로 예상되는 대지와 주로 사질토양으로 구성된 학교용지 는 낮은 유기물함량을 보였다. 지역별 분포에서는 경상남도 가 $2.9 \%$ 로 가장 높았고 충청북도가 $1.5 \%$ 로 가장 낮았다.

우리나라 토양 유기물함량 측정법으로 가장 널리 사용하 고 있는 방법이 Tyurin법이다. Table 2는 Tyurin법으로 농촌 진흥청 국립농업과학원에서 농경지 토양의 유기물함량을 연
Table 2. The organic matter contents $(\mathrm{g} / \mathrm{kg})$ listed in the Annual Report of the Monitoring Project on Agro-Environmental Quality ${ }^{11 \sim 14)}$

\begin{tabular}{cccc}
\hline Land uses & Points & Average $(\mathrm{g} / \mathrm{kg})$ & Year monitored \\
\hline \hline \multirow{2}{*}{ Paddy field } & 2070 & 26.0 & 2011 \\
& 2070 & 24.0 & 2007 \\
Field & 1753 & 24.0 & 2009 \\
Orchard & 1463 & 29.0 & 2010 \\
\hline
\end{tabular}

차적으로 조사한 평균값을 정리한 것이다. 논의 경우 2007 년과 2011년, 두번 조사되었고 2009년에는 밭, 2010년에는 과수원 토양을 조사하였다. 조사결과 농경지 토양의 유기 물함량 평균은 $2.4 \%$ 에서 $2.9 \%$ 범위에 있었다. ${ }^{11 \sim 15)}$ 본 연구 에서 Tyurin법으로 조사한 논과 밭의 유기물함량 평균은 $1.9 \%$ 와 $1.6 \%$ 로서 이전 국립농업과학원의 전국적 조사결과 보다 약간 낮은 값을 보였다. 그러나 논과 밭의 유기물함량 차이는 비슷하게 나타났다. 농업환경변동 보고서에서 논의 유기물함량이 밭보다 약간 높게 분포하였는데, 본 연구에 서도 논의 유기물함량 평균 및 사분위도는 밭의 경우보다 모두 높게 분포하였다.

우리나라 문헌들은 토양내 유기탄소 분석을 위한 화학적 산화법으로 Tyurin법을 사용하지만 외국문헌은 Tyurin법 대 신 Walkely \& Black법을 사용하고 있었다. 두 방법의 차이 는 Tyurin은 $200^{\circ} \mathrm{C}$ 에서 5 분간 직접 가열하지만 Walkely \& Black법은 자체 산화과정 중 발생되는 열을 이용하는 차이 가 있다.

\section{2. 강열감량방법에 의한 토양 유기물함량 측정 결과}

Table 3은 2014년 확대된 환경부 토양측정망 495개 지점

Table 3. Measurement of the organic matter content (\%) of soil taken from Korean soil quality monitoring network point by using the loss-on-ignition method $\left(450^{\circ} \mathrm{C}\right)$

\begin{tabular}{|c|c|c|c|c|c|c|c|c|c|}
\hline \multicolumn{9}{|c|}{ Regions } & \multirow{3}{*}{ Tota } \\
\hline & Gang- & Gyeong- & Gyeong- & Gyeong- & Gwang- & Daequ & Daejeon & Busan & \\
\hline & won & gi & nam & buk & ju & Datgu & valejeor & Dusall & \\
\hline Count & 52 & 50 & 70 & 73 & 2 & 2 & 4 & 2 & \\
\hline Average & 2.6 & 2.4 & 3.6 & 2.4 & 0.6 & 5.2 & 0.7 & 4.1 & \\
\hline \multirow[t]{2}{*}{ St. dev } & 1.6 & 2.1 & 2.6 & 1.5 & - & - & 0.6 & - & \\
\hline & Seoul & Sejong & Ulsan & Incheon & $\begin{array}{l}\text { Jeon- } \\
\text { nam }\end{array}$ & $\begin{array}{c}\text { Jeon- } \\
\text { buk }\end{array}$ & $\begin{array}{c}\text { Chung- } \\
\text { nam }\end{array}$ & $\begin{array}{c}\text { Chung- } \\
\text { buk }\end{array}$ & \\
\hline Count & 17 & 3 & 3 & 23 & 72 & 45 & 40 & 37 & 495 \\
\hline Average & 4.3 & 1.4 & 2.6 & 2.4 & 3.3 & 3.4 & 2.5 & 2.9 & 2.92 \\
\hline St. dev & 2.8 & 0.6 & 1.5 & 2.5 & 1.8 & 3.0 & 1.3 & 4.1 & 2.34 \\
\hline \multicolumn{10}{|c|}{ Land uses } \\
\hline & Park & $\begin{array}{l}\text { Paddy } \\
\text { field }\end{array}$ & $\begin{array}{c}\text { Residen- } \\
\text { tial }\end{array}$ & Forest & Field & $\begin{array}{c}\text { Religio- } \\
\text { us }\end{array}$ & $\begin{array}{c}\text { Playgro- } \\
\text { und }\end{array}$ & School & Total \\
\hline Count & 19 & 86 & 12 & 261 & 27 & 37 & 1 & 52 & 495 \\
\hline Average & 2.4 & 2.9 & 1.7 & 3.3 & 2.6 & 3.2 & 0.2 & 1.7 & 2.92 \\
\hline St. dev & 1.3 & 1.3 & 1.0 & 2.5 & 3.0 & 2.6 & - & 2.3 & 2.34 \\
\hline
\end{tabular}


을 선정하여 강열감량방법으로 토양 유기물 함량을 조사한 결과이다. 측정결과는 지역별과 토지용도별로 정리하였다. 495 개 지점에 대해 강열감량법에 의한 토양 유기물 함량은 평균 3.94\%를 나타내었다. Fig. 2는 box plot으로 평균, 중간 값 및 사분위도 등 측정결과의 세부 분포를 도시하고 있다. 지역별 결과 중 광주, 대구, 대전, 부산, 세종 및 울산과 토지 용도별 결과 중 체육용지 데이터는 그 수가 적어 box plot 도시에서 제외하였다.

Fig. 2는 강열감량방법에 의한 토지용도별 토양 유기물함 량 측정결과 평균값이 높은 순서로 Box plot을 정리하였다. 토양 유기물 함량 순서는 임야, 종교용지, 논, 밭, 공원, 대 지, 학교용지 순이었다. 가장 높은 평균값을 보인 지목은 임 야로서 $3.3 \%$ 였으며 가장 낮은 학교용지는 $1.7 \%$ 였다. 지역 별 분포에서는 서울이 $4.3 \%$ 로 가장 높았고 경북이 $2.4 \%$ 로 가장 낮았다.

강열감량법으로 측정된 토지용도별 유기물 함량 순서는 Tyurin법에 의한 분석결과와 유사하였다. 여전히 자연환경 요소가 많이 남아있거나 유기물 유입이 지속적으로 일어나 는 임야, 종교용지, 공원은 비교적 높은 유기물함량을 보이 나, 유기물 유입이 상대적으로 적은 대지와 대부분 사질토 양으로 구성된 학교용지는 낮은 유기물함량을 보였다. Fig. 1 과 2 를 비교해 보면 강열감량법에 의해 측정된 유기물함
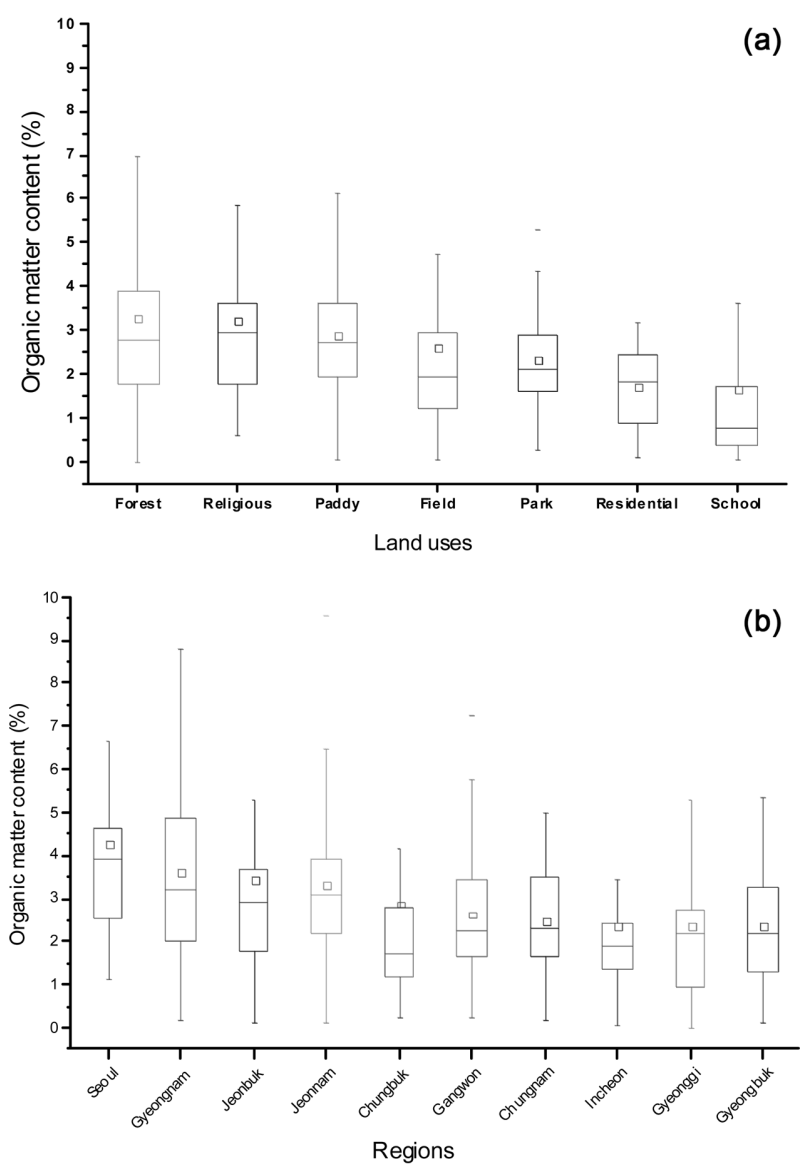

Fig. 2. Soil organic matter contents measured by loss of ignition method for land uses and regions.
량 데이터 분포는 비교적 Tyurin에 비해 높았고 그 편차 범 위도 상당히 넓게 분포하는 특징이 있었다.

\subsection{Tyurin법과 강열감량법(LOI, loss-on-ignition)의 비교}

Fig. 3은 Tyurin법과 강열감량법이 모두 적용된 309개 공 통 지점의 유기물함량 분석결과를 같이 도시하였다. Tyurin 법과 강열감량법에 의한 유기물 함량 측정값간의 회귀분석 결과 $y(\mathrm{LOI})=1.1963 x$ (Tyurin) $+0.6018, y$ (Tyurin) $=0.6257 x$ $(\mathrm{LOI})+0.0602$ 와 같은 회귀식이 얻어졌고 결정계수 $\mathrm{R}^{2}=$ $0.749, P$-value $<0.001$ 로 나타나 상관성이 높았다. 그러나, 강열감량법에 의한 유기물함량은 Tyurin법에 비해 약 1.2 배 높은 값으로 분포하고 있다. 또한 본 연구에서 도출한 회귀 식에 의하면 강열감량법에 의한 유기물함량 측정값은 $0.60 \%$ 이상 되어야 의미 있는 결과임을 시사한다.

강열감량법은 적용된 온도에 따라 유기물함량 측정결과 의 편차가 심한 것으로 알려져 있다. 지금까지 여러 문헌에 서 강열감량법에 적용된 온도범위는 $300^{\circ} \mathrm{C}$ 에서 $900^{\circ} \mathrm{C}$ 에 이 르기까지 다양하다. 높은 온도에서는 점토광물을 구성하고 있는 수분의 손실우려가 높고 탄산염, 무기탄소성분이 붕 괴되어 손실될 수 있어 과대 측정가능성이 높다. ${ }^{16)}$ Hoogsteen 등 $^{17)}$ 는 강열감량법에서 토양 유기물함량 측정의 영향인자 인 시료량, 온도 및 지속시간, 점토함량 등을 평가한 결과 $20 \mathrm{~g}$ 이상의 토양을 $550^{\circ} \mathrm{C}$ 에서 3 시간 가열하는 표준안을 제시하였고 Table 4에 나타낸 바와 같이 유기탄소함량비과 점토광물의 수분보정으로 유기탄소함량을 결정하였다. Table 4에 나타낸 바와 같이 Wang 등 ${ }^{18}$ 도 LOI와 토양 유기탄소 와의 관계식을 제시하고 있으며 온도와 지속시간은 $375^{\circ} \mathrm{C}$ 17 시간이다. 문헌에서 연구자들이 가장 많이 사용한 적용 온도와 시간은 $360^{\circ} \mathrm{C}$ 2시간이었다. 본 연구에서 사용한 450 ${ }^{\circ} \mathrm{C}$ 는 국립농업과학원의 토양화학분석법 ${ }^{7}$ 에서 제시된 온도 인 $420 \sim 450^{\circ} \mathrm{C}$ 범위 중 높은 값을 사용하였다.

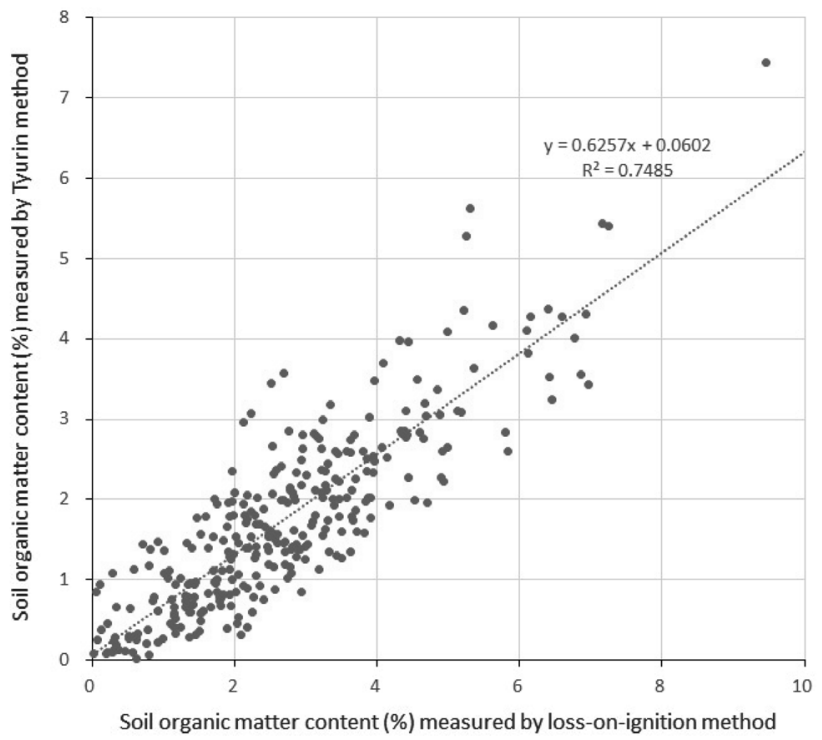

Fig. 3. Relationship between the loss-on-ignition (LOI) method and Tyurin method for the soil organic matter content 
Table 4. Relationship equations reported in the references for the soil organic carbon content and loss-on-ignition

\begin{tabular}{ccc}
\hline Reference & Relationship equation & Remarks \\
\hline \hline $\begin{array}{c}\text { Hoogsteen } \\
\text { et al. }{ }^{12)}\end{array}$ & $\mathrm{SOC}=\mathrm{a} \times(\mathrm{LOI}-\mathrm{b} \times \mathrm{C})$ & $\begin{array}{c}\text { a: Carbon content of SOM } \\
\text { b: Clay correction factor } \\
\mathrm{a}=0.55, \mathrm{~b}=0.075 \text { at } \\
550^{\circ} \mathrm{C} \text { for } 3 \text { hours }\end{array}$ \\
$\begin{array}{ccc}\text { Wang } \\
\text { et al. }{ }^{13)}\end{array}$ & $\mathrm{SOC}=(\mathrm{LOI}-4.189) /$ & $\mathrm{LOI}$ at $375^{\circ} \mathrm{C}$ for 17 hours \\
This study & $\mathrm{SOC}=0.364 \mathrm{LOI}+0.035$ & $450^{\circ} \mathrm{C}$ for 45 min \\
\hline
\end{tabular}

서 등 ${ }^{19}$ 도 Tyurin보다 연소방식의 유기물함량이 높게 얻 어짐을 보고하였다. 212개 농경지 토양에 대해 Tyurin법과 건식연소법(원소분석기)으로 유기물함량을 측정비교한 결 과 Tyurin법은 평균 $1.75 \%$, 건식연소법은 평균 $1.99 \%$ 로서 건식연소법이 높게 분석되었다. 이 값은 본 연구에서 Tyurin 법으로 조사한 논과 밭의 유기물함량 평균 $1.9 \%$ 와 $1.6 \%$ 와 유사한 값을 보여주고 있다. 그리고 원소분석기이지만 건 식연소법 결과의 분산이 보다 크게 나타나 Tyurin법보다 강 열감량법에서 분산폭이 크게 나타난 본 연구결과와 유사 한 결과를 보였다. 외국 문헌들 대부분도 화학적 산화법인 Walkely \& Black법보다 LOI에 의한 유기물함량값이 다소 높은 것으로 보고하고 있다.

토양유기물 함량 측정을 위한 강열감량법은 비교적 간단 하고 많은 량을 동시에 측정할 수 있다는 장점 등으로 현 장을 광범위하게 조사한 국외 연구문헌에서는 대부분 강열 감량법을 사용하고 있다. 그러나 가열온도 및 지속시간, 시 료량, 점토광물함량 등에 따라 편차가 심한 단점을 지니고 있다. 본 연구에서 Tyurin법과 강열감량법을 비교한 결과 강열감량법의 결과치가 Tyurin법의 결과치에 비해 크게 측 정되고 있지만 Tyurin법과의 상관관계가 성립되어 있는 바 토양측정망과 같이 정기적으로 다양한 지목에서 유기물함 량을 관측해야 하는 목적에서는 비교적 간편한 강열감량법 을 적용하여 유기물함량 변화를 모니터링 하는 방안이 적 합할 것으로 판단된다. 반면, 보다 정밀한 유기물 함량이나 유기탄소를 직접적으로 측정해야 하는 경우는 가열조건 및 토양조성에 영향을 받게 되는 강열감량법보다 Tyurin산화 법 및 직접 탄소측정방법(원소분석법) 등을 적용하는 것이 바람직하다.

\section{4. 토양유기물함량 결과의 활용}

본 연구는 우리나라 전역에 분포한 토양측정망 495 개 지 점의 토양유기물함량을 측정하였다. 495 개 지점은 16 개 시. 도와 8 개 지목으로 구성되었다. 각 지역 및 지목별 평균 토 양유기물함량 결과는 차후 토양오염물질에 대한 인체 및 생태위해성평가, 토양의 온실가스 저장능력 산정, 토양의 생산성 및 건강성 평가 등 다양한 분야의 기본데이터로 활 용될 수 있다.

우리나라 “토양오염물질 위해성평가 지침”(환경부 고시 제 2015-64호 $)^{4)}$ 에 제시된 「지하수노출농도 결정」, 「토양유래 실
외공기 휘발성물질 노출농도 결정」, ${ }^{\top}$ 토양유래 실내공기 유 입 휘발성물질 노출농도 결정」에 토양유기탄소비율이 기본 적으로 사용된다. 지침에는 부지의 토양유기탄소비율(유기 물함량)을 실측하여 이용할 것을 권고하고 있으나, 기본값 으로 0.016 (표토), 0.002 (심토)를 제시하고 있다. 이 값으로부 터 토양유기물함량을 환산하면 $2.75 \%$ (표토), $0.34 \%$ (심토)가 된다. 환산된 표토의 토양유기물함량 기본값 $2.75 \%$ 는 본 연구에서 제시한 평균값 $2.92 \%$ 와 매우 근접하다. 그러므로 각 지역별 및 각 지목별 토양오염물질 위해성평가를 수행함 에 있어 정확한 노출농도 결정을 위해 Table 1 과 3 의 토양 유기물 분석결과가 활용될 수 있을 것으로 기대된다.

\section{4. 결 론}

1) 환경부 토양측정망 338 개 지점에 대해 Tyurin방법으 로 토양 유기물 함량을 조사한 결과 평균 $1.90 \%$ 로 나타났 다. 토양 유기물 함량 평균값의 순서는 임야, 논, 종교용지, 공원, 대지, 밭, 학교용지 순이었다. 임야의 평균 유기물 함 량은 $2.0 \%$ 였으며 가장 낮은 학교용지는 $1.6 \%$ 였다.

2) 환경부 토양측정망 495 개 지점에 대해 강열감량방법 으로 토양 유기물 함량을 조사한 결과 평균 $2.92 \%$ 로 나타 났다. 토지용도별 유기물 함량 순서는 Tyurin법에 의한 분 석결과와 유사하였다. 여전히 자연환경 요소가 많이 남아 있거나 유기물 유입이 지속적으로 일어나는 임야, 종교용지, 공원은 비교적 높은 유기물함량을 보이나, 유기물 유입이 상대적으로 적은 대지와 대부분 사질토양으로 구성된 학교 용지는 낮은 유기물함량을 보였다.

3) Tyurin법과 강열감량법이 모두 적용된 309개 공통 지 점 유기물함량 분석결과에 대한 회귀분석결과 $y$ (Tyurin) $=$ $0.6257 x(\mathrm{LOI})+0.0602$ 와 같은 회귀식이 얻어졌고 결정계수 $\mathrm{R}^{2}=0.749, P$-value $<0.001$ 로 나타나 상관성이 높았다.

4) 본 연구에서 Tyurin법과 강열감량법을 비교한 결과 강 열감량법의 결과치가 Tyurin법의 결과치에 비해 크게 측정 되고 있지만 Tyurin법과의 상관관계가 성립되는 바, 여러 토지용도에서 많은 양의 토양시료를 측정해야 하는 목적 등에서는 비교적 간편한 강열감량법도 적용할 수 있을 것 으로 판단된다.

5) 본 연구에서 제시된 각 지역 및 지목별 평균 토양유기 물함량 결과는 차후 토양오염물질에 대한 인체 및 생태위 해성평가, 토양의 온실가스 저장능 산정, 토양의 생산성 및 건강성 평가 등 다양한 분야의 기본데이터로 활용될 수 있 을 것으로 기대된다.

\section{Acknowledgement}

본 연구는 한국연구재단(NRF-2015R1D1A1A01059664)에 의해 지원되었습니다. 이에 감사드립니다. 


\section{References}

1. Hyeon, G. S., Park, C. S. Jung, S. J. Rim, S. K. and Um, K. T., "Soil CEC for textural classes in Korea," J. Korean Soc. Soil Sci. Fert., 24(1), 10 16(1991).

2. Stevenson, F. J., "Humus Chemistry: Genesis, Composition, Reactions," 2nd ed, Wiley(1994)

3. Nortcliff, S., "Soil Organic Matter-the potential benefits and necessary precautions required in the use of composts and biosolids as soil amendments in agroecosystems,'In: Yang, J. E., Sa, T. M. and Kim, J. J. (eds.) Application of the Emerging Soil Researches to the Conservation of Agricultural Ecosystems. KSSSF-KSAE-RDA, Seoul, pp. 81 93(2005).

4. Ministry of Environment, Risk Assessment Guidelines for Soil Contamination, Sejong, Bulletin 2015-64, Korea(2015).

5. Intergovernmental Technical Panel on Soils, Can Carbon (SOC) Offset the Climate Change, Food and Agriculture Organization of the United Nations, Rome, Italy(2015).

6. Bot, A. and Benites, J., The Importance of Soil Organic Matter: Key to drought-resistant soil and sustained food and production, Food and Agriculture Organization of the United Nations, Rome, Italy(2005).

7. National Academy of Agricultural Science, Method of Soil Chemical Analysis, Korea(2010).

8. Wang, J. P., Wang, X. J. and Zhang, J., "Evaluating Losson-Ignition Method for Determinations of Soil Organic and Inorganic Carbon in Arid Soils of Northwestern China," $\mathrm{Pe}$ dosphere, 23(5), 593 599(2013).

9. Ministry of Environment, Standard Methods for Soil Analysis, ES07301.1 Moisture Content(2009).

10. Ministry of Environment, Standard Methods for Soil Analysis,
ES07130 Sampling and preparing of soil sample(2009).

11. Oh, W. K., "Effects of organic materials on soil chemical properties," J. Korean Soc. Soil, Sci. Fert., 11(3), 161 174 (1978).

12. National Academy of Agricultural Science, 2007 Annual Report of the Monitoring Project on Agro-Environmental Quality, Rural Development Aency(2008).

13. National Academy of Agricultural Science, 2009 Annual Report of the Monitoring Project on Agro-Environmental Quality, Rural Development Aency(2010).

14. National Academy of Agricultural Science, 2010 Annual Report of the Monitoring Project on Agro-Environmental Quality, Rural Development Aency(2011).

15. National Academy of Agricultural Science, 2011 Annual Report of the Monitoring Project on Agro-Environmental Quality, Rural Development Aency(2012).

16. Mikutta, R., Kleber, M., Kaiser, K. and Jahn, R., "Organic matter removal from soils using hydrogen peroxide, sodium hypochlorite, and disodium peroxodisulfate," Soil Sci. Soc. America J., 69(9), 120 135(2015).

17. Hoogsteen, M. J. J., Lantinga, E. A., Bakker, E. J., Groot, J. C. J. and Tittonell, P. A., "Estimating soil organic carbon through loss on ignition: effects of ignition conditions and structural water loss," Eur. J. Soil Sci., 66(2), 320 328(2015).

18. Wang, X., Wang, J. and Zhang, J., "Comparisons of three methods for organic and inorganic carbon in calcareous soils of Northwestern China," PLOS ONE, 7(8), 1 6(2012).

19. Seo, M. C., So, K. H., Ko, B. G. and Son, Y. K., "Comparison of tyurin method and dry combustion method for carbon analysis in soils of low inorganic carbon content," J. Korean Soc. Soil, Sci. Fert., 37(5), 315 321(2004). 